Vol. 44, N. 4 : pp. 337 - 342, December, 2001

ISSN 1516-8913 Printed in Brazil

BRAZILIAN ARCHIVES OF BIOLOGY AND TECHNOLOGY

AN INTERNATIONAL JOURNAL

\title{
Performance of Differents Genotyps of Brazilian Orchid Cultivation in Alternatives Substrates
}

\author{
Ricardo Tadeu de Faria*; Luciana do Valle Rego; Anderson Bernardi and Hugo Molinari \\ Departamento de Agronomia da Universidade Estadual de Londrina. Caixa Postal 6001, Cep 86051-970, Londrina \\ - PR, Brazil
}

\begin{abstract}
Two native Brazilian orchid especies, Oncidium baueri and Maxillaria picta, were grown in different substrate mixtures. The plants were cultivated in ceramic pots in a greenhouse with 50\% of shadind light and watered three times a week. The following substrates were used: 1) de-fibered xaxim; 2)xaxim cubes; 3) vermiculite; 4) carbonized rice husk; 5) charcoal; 6) charcoal + carbonized rice husk; 7) crocks; 8) vermiculite and charcoal; 9) vermiculite + carbonized rice husks; 10) extruded polystyrene + charcoal; 11) pine bark + charcoal + extruded polystyrene; 12) vermiculite + carbonized rice husks + extruded polystyrene + charcoal; 13) pine bark. The substrate ratio was 1:1 in the mixture. NPK 10-10-10 leaf fertilizer was applied every thirty days and castor bean cake and bone powder organic fertilizer were applied every ninety days. A randomized complete block design was used with 10 replications. Growth and rooting were assessed after eight months. The best alternative substrate to O. baueri was vermiculie and the best alternatives substrates to $M$. picta were vermiculite and charcoal and vermiculite + carbonized rice husks.
\end{abstract}

Key words: Orchidaceae, Maxillaria picta, Oncidium baueri, growing media

\section{INTRODUCTION}

Orchids are the most appreciated of ornamental plants with the highest commercial value. But in Brazil many species are threatened with extinction by forest devastation and predatory collection (Kerbauy, 1984). Orchids are not parasite plants, as they do not feed on the host but use it only for fixation. They are generally epiphyte (air roots) and live on trees or on stones (in tropical regions) and soil (in temperate zones), although there are many soil orchids in tropical regions (Demattê \& Demattê, 1996).

Epiphyte orchids have air roots and are subjected to prolonged periods of drought. Moisture is provided by rainfall, night dew and relative air humidity. When the substrate has ideal texture and drainage, water is absorbed by a spongy structure formed by layers of dead cells which covers the roots known as "velame" (a protective layer). These plants survive prolonged drought, but they die if there is inadequate drainage (Bomba, 1975; Batchelor, 1981; Demattê \& Demattê, 1996). Nutrition, which is different for each species, must also be balanced, so that there is no reduction in the germination, growth, development and dry material production (Arditti, 1967; Arditti \& Ernest, 1984; Stancato \& Faria, 1996).

The ideal substrate for ornamental plant cultivation should be available in great quantity and be easy to handle and cheap. Brazil offers

* Author for correspondence 
limited substrate options, unlike other countries which specialize in commercialization of the more exotic inputs for ornamental plant cultivation such as different tree barks, dry pine leaves, different sized stones and rare types of stones, and moss imported from New Zealand (Oliveira, 1993b; Ortega et al, 1996).

Xaxim is the preferred substrate among Brazilian orchid growers and is formed from the adventitious roots of some ferns from the Dicksoniaceae and Cyatheaceae families. It is usually used in the form of fibers and not powder. Ready-made de-fibered xaxim can be purchased or made by defibering xaxim vases, plaques or sticks. Xaxim powder is extracted by sieving, washing in running water or even 'beating' it through a large mesh sieve. It is considered an excellent substrate for orchid cultivation because it retains large quantity of water and remains moist for a long time in the absence of rain or irrigation it provides water for the "velame" through contact and raise the relative humidity of the air in the environment close to the vase, maintaining the relative air humidity (Oliveira 1993a, Demattê \& Demattê, 1996).

Uncontrolled extraction is leading to the extinction of the plants that supply xaxim in Brazil. These plants take 15 to 18 years to reach the ideal stage for extraction and at the present time there is no commercial production (Lorenzi \& Sousa, 1996). The use of alternative substrates for orchid cultivation would benefit the environment by preserving the "Samabaiaçu" (fern) (Dicksonia sellowiana Hook) which has been used for many years in orchid cultivation (Demattê \& Demattê, 1996; Lorenzi \& Sousa, 1996; Tortato, 1998; Stancato et al, 1999).

This study was carried out to assess the growth of native Brazilian orchid plants using different substrates.

\section{MATERIAL AND METHODS}

The experiment was conducted at the Agrarian Science Center at the Londrina State University (UEL) located at $23^{\circ} 23^{\prime} \mathrm{S}$ and $51^{\circ} 11^{\prime} \mathrm{W}$ and mean height $566 \mathrm{~m}$ above sea level. The climate is Cfa according to the Koppen classification (humid subtropical climate). The experiment was carried out in a greenhouse with $50 \%$ of shading provided by a black polypropylene screen. Two species of orchid native to Brazil, Maxillaria picta and Oncidium baueri were used. M. picta is a medium sized epiphyte orchid plant which lives on the middle area of tree trunks in the primitive forest at $1100-1400 \mathrm{~m}$ above sea level; O. baueri is an epiphyte species common in the Atlantic Forest (Miller, 1996).

The $M$ picta plants were collected from a tree clump on the Londrina State University campus and divided with four pseudobulbs. The $O$ baueri plants used in the experiment were collections of in vitro germinated seeds with an initial height of $5.62 \mathrm{~cm}+1.5 \mathrm{~cm}$.

A randomized complete block design was used with thirteen treatments and ten replications. The treatments were 1) de-fibered xaxim; 2)xaxim cubes; 3) vermiculite; 4) carbonized rice husk; 5) charcoal; 6) charcoal + carbonized rice husk; 7) crocks; 8) vermiculite and carbon; 9) vermiculite + carbonized rice husks; 10) extruded polystyrene + charcoal; 11) pine bark + charcoal + extruded polystyrene; 12) vermiculite + carbonized rice husks + extruded polystyrene + charcoal; 13) pine bark. The substrates were mixed at the ratio of 1 : 1 up to $5 \mathrm{~cm}$ of the upper part of the case. The pine bark was soaked in water for 48 hours to remove the tanin which is toxic.

Ceramic pots $(20 \mathrm{~cm}$ dia $\times 12 \mathrm{~cm} \mathrm{~h})$ with six side holes and a hole at the bottom were used to give good aeration and drainage to the root system. NPK formula 10-10-10 leaf fertilizer $(1 \mathrm{~g} / \mathrm{L})$ was applied every thirty days and castor bean cake (1g/vase) and bone powder (1g/pot) organic fertilizer at a ratio of 1 to 1 (Silva, 1986) was applied every 90 days. The plants were spray irrigated in the morning for three minutes, every three days in the winter and every day in the summer.

Plant length (CP), number of buds (NB), bulb length $(\mathrm{CB})$ and bulb width (LB) were assessed in $O$ baueri while the leaf length $(\mathrm{CF})$, leaf width (LF), number of buds (NB), bulb length (CB) and bulb width (LB) were assessed for M. picta. The assessments were made per unit after an eight month treatment.

\section{RESULTS AND DISCUSSION}

Table 1 shows the mean values which demonstrate the results of the different substrate mixtures in $O$ baueri cultivation for the plant length $(\mathrm{CP})$, bulb length (CCB) and bulb width (LB). 
The highest means for plant length in the $O$ baueri species were found in the treatments with xaxim cubes, vermiculite and de-fibered xaxim with $25.67 \mathrm{~cm}, 22.34 \mathrm{~cm}$ and $19.71 \mathrm{~cm}$ respectively.
These results showed that vermiculite could be considered an excellent substitute substrate for xaxim.

Table 1 - Mean values for plant length $(\mathrm{cm})$, number of buds, bulb length $(\mathrm{cm})$ and bulb width $(\mathrm{cm})$ for $O$ baueri after 8 months treatment. Londrina PR, 1999.

\begin{tabular}{|c|c|c|c|c|}
\hline Treatment & $\begin{array}{c}\text { Plant } \\
\text { Length } \\
(\mathrm{cm})\end{array}$ & $\begin{array}{c}\text { Number of } \\
\text { buds }\end{array}$ & $\begin{array}{c}\text { Bulb } \\
\text { Length } \\
(\mathrm{cm})\end{array}$ & $\begin{array}{l}\text { Bulb width } \\
\quad(\mathrm{cm})\end{array}$ \\
\hline De-fibered xaxim & $19.71 \mathrm{ab}^{* *}$ & $1.00 \mathrm{a}$ & $5.37 \mathrm{abc}$ & $1.98 \mathrm{ab}$ \\
\hline Xaxim cubes & $25.67 \mathrm{a}$ & $1.04 \mathrm{a}$ & $5.70 \mathrm{ab}$ & $2.02 \mathrm{a}$ \\
\hline Vermiculite & $22.34 \mathrm{ab}$ & $1.00 \mathrm{a}$ & $6.11 \mathrm{a}$ & $1.80 \mathrm{abc}$ \\
\hline Carbonized rice husk & $15.39 \mathrm{bc}$ & $1.00 \mathrm{a}$ & $4.88 \mathrm{abcd}$ & $1.60 \mathrm{abcd}$ \\
\hline Charcoal & $11.43 \mathrm{~cd}$ & $1.00 \mathrm{a}$ & 4.20 abcde & $1.43 \mathrm{abcd}$ \\
\hline Charcoal + carbonized rice husk & $11.60 \mathrm{~cd}$ & $1.00 \mathrm{a}$ & 4.31 abcde & $1.42 \mathrm{abcd}$ \\
\hline Crocks & $8.24 \mathrm{~d}$ & $1.00 \mathrm{a}$ & 4.09 bcde & $1.33 \mathrm{bcd}$ \\
\hline Vermiculite + charcoal & $7.79 \mathrm{~d}$ & $0.80 \mathrm{a}$ & $2.84 \mathrm{e}$ & $1.06 \mathrm{~d}$ \\
\hline Vermiculite + carbonized rice husk & $10.24 \mathrm{~cd}$ & $0.94 \mathrm{a}$ & $3.08 \mathrm{de}$ & $1.33 \mathrm{bcd}$ \\
\hline Extruded polystyrene +charcoal & $8.63 \mathrm{~cd}$ & $0.80 \mathrm{a}$ & $2.91 \mathrm{de}$ & $1.13 \mathrm{~d}$ \\
\hline Pine bark + charcoal + extruded polystyrene & $8.72 \mathrm{~cd}$ & $0.90 \mathrm{a}$ & $3.01 \mathrm{de}$ & $1.22 \mathrm{~cd}$ \\
\hline $\begin{array}{l}\text { Vermiculite }+ \text { carbonized rice husk }+ \text { extruded } \\
\text { polystyrene }+ \text { charcoal }\end{array}$ & $9.99 \mathrm{~cd}$ & $1.00 \mathrm{a}$ & 3.53 cde & $1.29 \mathrm{~cd}$ \\
\hline Pine bark & $5.19 \mathrm{~d}$ & $0.80 \mathrm{a}$ & $3.09 \mathrm{de}$ & $1.10 \mathrm{~d}$ \\
\hline C.V. & 27.04 & 25.86 & 22.61 & 20.17 \\
\hline DMS & 7.11 & 0.36 & 2.02 & 0.66 \\
\hline
\end{tabular}

data transformed in square root

*** measurements followed by the same letter do not differ by the Tukey test at $1 \%$ and $5 \%$

The lowest means for plant length were found for the crocks, vermiculite + charcoal and pine bark, with $8.24 \mathrm{~cm}, 7.79 \mathrm{~cm}$ and $5.19 \mathrm{~cm}$ respectively (Table 1).

There was no significant difference among the treatments for number of buds. The highest means for bulb length $(\mathrm{CB})$ were found in the vermiculite and xaxim cubes treatments with $6.11 \mathrm{~cm}$ and $5.7 \mathrm{~cm}$ respectively. The lowest mean was found in the vermiculite + charcoal substrate mixture with $2.84 \mathrm{~cm}$ (Table 1 ).

The highest means for bulb width were found for xaxim cubes and de-fibered xaxim with $2.02 \mathrm{~cm}$ and $1.98 \mathrm{~cm}$, respectively. Vermiculite substrate gave a satisfactory result

$(1.80 \mathrm{~cm})$ and this could also be considered as an alternative substrate to substitute xaxim. Stancato et al (1999) suggested that bark with forest essence instead of xaxim in Dendrobium nobile CV. Gilblanc orchid cultivation. The lowest means for bulb width were found in the extruded polystyrene + charcoal, pine bark and vermiculite with $1.13 \mathrm{~cm}, 1.10 \mathrm{~cm}$ and $1.06 \mathrm{~cm}$ respectively (Table 1).
According to Figure 1, xaxim cubes (T2) and vermiculite (T3) were the substrates which had the best results for $O$ baueri cultivation in the greenhouse.

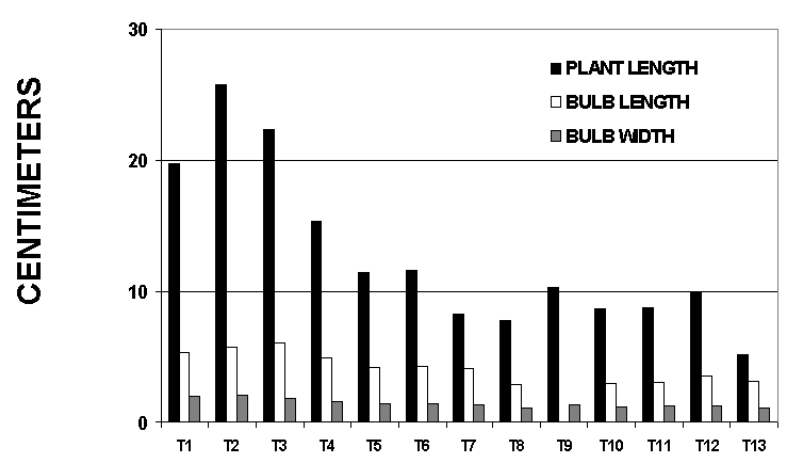

Figure 1 - Means values for plant length $(\mathrm{cm})$, bulb length $(\mathrm{cm})$ and bulb width $(\mathrm{cm})$ for $O$ baueri in the different substrate mixtures.

\section{TREATMENTS}

Abbreviations used: 1) de-fibered xaxim (T1); 2)xaxim cubes (T2); 3) vermiculite (T3); 4) carbonized rice husk (T4); 5) charcoal (T5); 6) charcoal + carbonized rice husk(T6); 7) crocks (T7); 8) vermiculite and carbon (T8); 9) vermiculite + carbonized rice husks (T9); 10) extruded polystyrene + charcoal $(\mathrm{T} 10) ; 11)$ pine bark + charcoal + extruded polystyrene (T11); 12) vermiculite + carbonized rice husk + extruded polystyrene + charcoal (T12); 13) pine bark (T13). 
Table 2 shows the significant differences among the different substrate mixtures in Maxillaria picta cultivation for the leaf length (CF), leaf width (LF) and bulb width (LB) variables.

Table 2 - Mean values of leaf length, leaf width, number of buds, bulb length and bulb width for Maxillaria picta after 8 months treatment. Londrina, PR, 1999.

\begin{tabular}{|c|c|c|c|c|c|}
\hline Treatment & $\begin{array}{l}\text { Leaf length } \\
(\mathrm{cm})\end{array}$ & $\begin{array}{l}\text { Leaf width } \\
(\mathrm{cm})\end{array}$ & $\begin{array}{l}\text { Number } \\
\text { of buds* }\end{array}$ & $\begin{array}{l}\text { Bulb length } \\
(\mathrm{cm})\end{array}$ & $\begin{array}{l}\text { Bulb width } \\
\quad(\mathrm{cm})\end{array}$ \\
\hline De-fibered xaxim & $20.59 \mathrm{ab}^{* *}$ & $2.21 \mathrm{a}$ & $1.34 \mathrm{a}$ & $4.45 \mathrm{ab}$ & $3.37 \mathrm{ab}$ \\
\hline Xaxim cubes & $21.16 \mathrm{a}$ & $2.10 \mathrm{ab}$ & $1.35 \mathrm{a}$ & $4.71 \mathrm{a}$ & $3.51 \mathrm{a}$ \\
\hline Vermiculite & $17.57 \mathrm{abcd}$ & $1.85 \mathrm{abc}$ & $1.20 \mathrm{a}$ & $4.22 \mathrm{ab}$ & $2.86 \mathrm{abcd}$ \\
\hline Carbonized rice husk & $16.26 \mathrm{abcd}$ & $1.67 \mathrm{bc}$ & $1.16 \mathrm{a}$ & $4.11 \mathrm{ab}$ & $2.99 \mathrm{abc}$ \\
\hline Charcoal & $15.46 \mathrm{~cd}$ & $1.58 \mathrm{bc}$ & $1.17 \mathrm{a}$ & $3.88 \mathrm{ab}$ & $2.5 \mathrm{~cd}$ \\
\hline Charcoal + carbonized rice husk & $16.07 \mathrm{abcd}$ & $1.55 \mathrm{c}$ & $1.08 \mathrm{a}$ & $4.06 \mathrm{ab}$ & $2.54 \mathrm{~cd}$ \\
\hline Crocks & $13.70 \mathrm{~cd}$ & $1.42 \mathrm{c}$ & $1.02 \mathrm{a}$ & $3.62 \mathrm{ab}$ & $2.13 \mathrm{~d}$ \\
\hline Vermiculite + charcoal & $18.66 \mathrm{abc}$ & $1.84 \mathrm{abc}$ & $1.20 \mathrm{a}$ & $4.43 \mathrm{ab}$ & $3.15 \mathrm{abc}$ \\
\hline Vermiculite + carbonized rice husk & $17.45 \mathrm{abcd}$ & $1.83 \mathrm{abc}$ & $1.20 \mathrm{a}$ & $4.61 \mathrm{a}$ & $3.45 \mathrm{ab}$ \\
\hline Extruded polystyrene +charcoal & $15.92 \mathrm{bcd}$ & $1.55 \mathrm{c}$ & $1.12 \mathrm{a}$ & $4.12 \mathrm{ab}$ & $2.72 \mathrm{bcd}$ \\
\hline $\begin{array}{l}\text { Pine bark }+ \text { charcoal }+ \text { extruded } \\
\text { polystyrene }\end{array}$ & $13.05 \mathrm{~d}$ & $1.51 \mathrm{c}$ & $1.04 \mathrm{a}$ & $4.13 \mathrm{ab}$ & $2.60 \mathrm{~cd}$ \\
\hline $\begin{array}{l}\text { Vermiculite }+ \text { carbonized rice husk }+ \\
\text { extruded polystyrene }+ \text { charcoal }\end{array}$ & $15.51 \mathrm{bcd}$ & $1.66 \mathrm{bc}$ & $1.30 \mathrm{a}$ & $4.11 \mathrm{ab}$ & $3.10 \mathrm{abc}$ \\
\hline Pine bark & $16.30 \mathrm{abcd}$ & $1.72 \mathrm{abc}$ & $1.17 \mathrm{abc}$ & $4.35 \mathrm{ab}$ & $3.08 \mathrm{abc}$ \\
\hline C.V. & 20.17 & 20.48 & 22.70 & 13.79 & 16.97 \\
\hline DMS & 5.11 & 0.54 & 0.40 & 0.88 & 0.75 \\
\hline
\end{tabular}

data transformed in square root

* measurements followed by the same letter do not differ by the Tukey test at $1 \%$ and $5 \%$

The highest means for leaf length (CF) in M. picta were in xaxim cubes and de-fibered xaxim substrates with $21.16 \mathrm{~cm}$ and $20.59 \mathrm{~cm}$ respectively. The vermiculite + charcoal substrate gave a good result of $18.66 \mathrm{~cm}$, and could be used as an alternative substrate to xaxim. The lowest mean was found for pine bark + charcoal + extruded polystyrene with $13.05 \mathrm{~cm}$ (Table 2 ).

The best results for leaf length were found in the means for de-fibered xaxim and xaxim cubes with $2.21 \mathrm{~cm}$ and $2.10 \mathrm{~cm}$ respectively. The results for leaf width in the vermiculite, vermiculite + charcoal, vermiculite + carbonized rice husk and pine bark substrates were $1.85 \mathrm{~cm}, 1.84 \mathrm{~cm}$, $1.83 \mathrm{~cm}$ and $1.72 \mathrm{~cm}$, respectively. The less significant means of the substrate mixtures were for charcoal + carbonized rice husk, extruded polystyrene + charcoal, pine bark + charcoal + extruded polystyrene and crocks, with $1.55 \mathrm{~cm}$, $1.55 \mathrm{~cm}, 1.51 \mathrm{~cm}$ and $1.42 \mathrm{~cm}$, respectively (Table 2). There was no significant difference for the bulb number and length variables among the substrate mixtures (Figure 2).

The highest means for bulb width (LB) were found in xaxim cubes, vermiculite + carbonized rice husk and de-fibered xaxim substrates with $3.51 \mathrm{~cm}, 3.45 \mathrm{~cm}$ and $3.37 \mathrm{~cm}$, respectively. The lowest mean was for cultivation in crocks with $2.13 \mathrm{~cm}$ (Table 2). According to Sousa (1995) the carbonized rice husk added to sand and earth have been a good substrate for crisanthem's cultivation. The best substrates for $O$ baueri species growth were xaxim cubes and vermiculite.

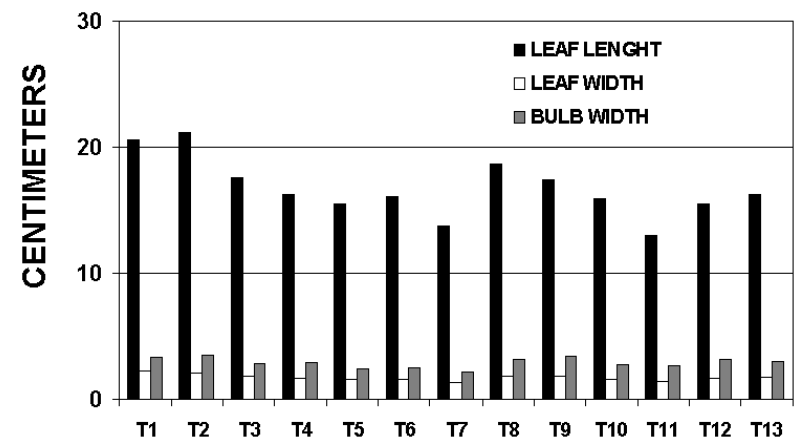

Figure 2 - Mean values of leaf length $(\mathrm{cm})$, leaf width $(\mathrm{cm})$ and bulb width for Maxillaria picta after in the different substrate mixtures.

\section{TREATMENTS}

Abbreviations used: 1) de-fibered xaxim (T1); 2)xaxim cubes (T2); 3) vermiculite (T3); 4) carbonized rice husk (T4); 5) charcoal (T5); 6) charcoal + carbonized rice husk(T6); 7) crocks (T7); 8) vermiculite and carbon (T8); 9) vermiculite + carbonized rice husks (T9); 10) extruded polystyrene + charcoal (T10); 11) pine bark + charcoal + extruded polystyrene (T11); 12) vermiculite + carbonized rice husk + extruded polystyrene + charcoal $(\mathrm{T} 12) ; 13)$ pine bark (T13) 
Demattê \& Demattê (1996) found that xaxim can be substituted by pure coconut fiber, coconut fiber mixed with charcoal and eucalyptus bark for the cultivation of some orchids. Kampf (2000) reported that crocks and cork and extruded polystyrene together are a good substrate for orchid's cultivation.

The $M$. picta orchid grew most in de-fibered xaxim, xaxim cubes and vermiculite + carbonized rice husk substrates (Figure 2). Bellé, (1999), observed that xaxim was an excellent substrate to cultivate the Maxillaria cosanguinea orchid but suggested substituting $50 \%$ of xaxim by pine bark as a way of preserving the "Samabaiaçu" (fern) (Dicksonia sellowiana Hook) from which the xaxim was extracted.

Use of xaxim has been criticized due to its actual extinguish process. Because of it a law (9.519) was created on January 21, 1992, according the constitution of the Rio Grande do Sul state that forbide xaxin extration from natives forests (Kampf, 2000). This law helps to keep the native ferests on the territory of the Santa Catarina state and Rio Grande do Sul state, where the largest illegal extration take place (Silva, 1986).

These results showed, It has been observed the need of more research in the sense of preserving the xaxim and discovering new substrates for the orchidaceae family, which presents a great genetic variability and different phisiological needs.

In this study, the best growth results for the $O$. baueri species were observed in xaxim cubes and vermiculite treatments. The xaxim can be substituted by vermiculite in $O$ baueri cultivation. The M. picta species grew best in xaxim cubes, de-fibered xaxim and charcoal + vermiculite substrates under greenhouse conditions. The $M$. picta species can also be cultivated in vermiculite + charcoal and vermiculite + carbonized rice husk substrates in place of xaxim.

\section{ACKNOWLEDGEMENT}

We are grateful to Conselho Nacional de Desenvolvimento Científico e Tecnológico (CNPq) for financial suport

\section{RESUMO}

Diferentes misturas de substratos foram estudados para duas variedades de orquídeas nativas do Brasil: Oncidium baueri e Maxillaria pictea. As plantas foram cultivadas em vasos de cerâmica em casa de vegetação com $50 \%$ de luminosidade e regadas 3 vezes por semana. Os substratos utilizados foram os seguintes: 1)xaxim desfibrado; 2)xaxim e cubos; 3)vermiculita; 4)casca de arroz carbonizada; 5)carvão; 6)carvão + casca de arroz carbonizada; 7)cacos de cerâmica; 8)vermiculita + carvão; 9)vermiculita + casca da arroz carbonizada; 10)isopor + carvão; 11)casca de pinus + carvão + isopor; 12) vermiculita + casca da arroz carbonizada + isopor + carvão; 13)casca de pinus. A proporção dos substratos foi de 1:1 na mistura. A cada trinta dias foi realizado uma adubação foliar com NPK: 10-10-10 e a cada 90 dias uma adubação orgânica com torta de mamona e farinha de osso. O delineamento experimental foi de blocos ao acaso com 10 repetições. As avaliações do crescimento e enraizamento foram feita após 8 meses. Para O.baueri o melhor substrato alternativo foi a vermiculita e para $M$. picta os melhores substratos alternativos foram vermiculita + carvão e vermiculita + palha de arroz carbonizada.

\section{REFERENCES}

Arditti, J. (1967), Factors affecting the germination of seeds. Bot. Rev. 33(1), 1-97.

Arditti, J. and Ernest, R. (1984), Physiologt of germination of orchid seeds. In Arditti. J. (ed): Orchid Biology. Reviews and Perspectives. Vol. III. Chaper 4. Comstock Publishing Associates, Ithaca. USA. 177-122.

Batchelor, S. R. (1981), Orchid culture - 6 - watering. American Orchid Society Bulletin, West Palm Beach, 50(8), 945-952.

Bellé, S. (1999), Substrato para o cultivo de Maxillaria consanguinea KLOTZSCH var. pallida Hoehne. $1^{\circ}$ Encontro Nacional sobre Substrato para Plantas, Programa e Resumos; Porto Alegre, 55-56.

Bomba, G. A. (1975), A different of growing epiphytic orchids. American Orchid Society Bulletin, West Palm Beach. 44, 205-210.

Demattê, J. B. J.; Demattê, M. E. S. P. (1996), Estudos Hídricos com substratos vegetais para o cultivo de orquídeas epífitas. Pesquisa Agropecuária Brasileira, Brasília, 31(11), 803-813. 
Kampf, A. N. (2000), Produção comercial de Plantas Ornamentais. Ed. Agropecuária. RS. 45-71.

Kerbauy, G. B. (1994), Plant regeneration of Oncidium varicosum (Orchidaceae) by means of root tip cultura. Plant and Cell. 3, 27-29.

Lorenzi, H. and Sousa, H. M. (1996), Plantas Ornamentais do Brasil. Ed Plantarum Ltda Nova Odessa. Brasil. 1, pp.650.

Miller, D.; Warren, R. (1996), Orquídeas do Alto da Serra. Salamandra Ltda; 1, p.200-228.

Oliveira, S. A. A. (1993a), Noções sobre cultivo de orquídeas. Boletin da CAOB, 5(1), 29-35.

Oliveira, S. A.A. (1993b) Substratos no Brasil. Boletin da $C A O B, \mathbf{5}(3), 25$.

Orterga, M. C.; Moreno, M. T; Ordovas, J. and Aguado, M. T. (1996), Behaivour of different horticultural species in phytotoxicity bioassays of bark substrates. Scientia Horticulturae. 66, 125-132.

Silva, W. (1986), Cultivo de Orquideas no Brasil. Ed nobel. São Paulo, Brasil. 96p.
Sousa, M. M.; Lopes, L. C. and Fontes, L. E. F. (1995), Avaliação de Substratos para o cultivo de Crisântemo (Chrysanthemum morifolium Ramat., Compositae) 'White Polaris' em vaso. Revista Brasileira de Horticultura Ornamental. 1(2), 71-77.

Stancato, G. C. and Faria, R. T. (1996), In vitro Growth and Mineral nutrition of the Lithophytic orchid Laelia cinnabarina Batem. (Orchidaceae) 1: efects of Macro and Microelements. Lindleyana . 11(1), 41-43.

Stancato, G. C.; Abreu, M. F.; Bertton, R.; Kerbauy, G. B. (1999), Análise de alguns substratos para o cultivo de orquídeas epífitas e Avaliação do crescimento em plantas de Dendrobium nobile CV. Gilblanc. $1^{\mathrm{O}}$ Encontro Nacional sobre Substrato para Plantas, Programa e Resumos. Porto Alegre, p.65-66.

Tortato, M. A. (1998), Cultivo de orquídeas em nó de pinho. Boletin da CAOB, 34, 118-122.

Received: May 08, 2000; Revised: July 16, 2000 Accepted: November 27, 2000. 